\title{
BETWEEN TRUTH AND RESPECT - TOWARDS AN ETHICS OF CARE IN JOURNALISM ${ }^{1}$
}

\author{
Carlos Camponez ${ }^{2}$ \\ c.camponez@sapo.pt \\ Departamento de Filosofia, Comunicação e Informação, Faculdade de Letras da Universidade de Coimbra \\ Largo da Porta Férrea, 3004-530 Coimbra, Portugal
}

\begin{abstract}
This article seeks to explore the contributions of an ethic of care for journalism. Far from refusing the objectivity paradigm, the ethics of care emphasizes the role of journalism in its engagement with the public sphere and democracy, stressing the social responsibility dimension based on respect for the different stakeholders in the complex process of information: the subject who informs, the public and the information sources; journalism as a professional culture. This perspective can be a response to the contradictions that we find across the normative field of journalism, tightly placed between the paradigm of objectivity, freedom of speech and the market demands. In a communication where the logics of commodification, entertainment and audiences prevail, the ethics of care based on respect can become an alternative response towards a new public contract and journalism's credibility.
\end{abstract}

KEYWORDS

Ethics of care; journalistic ethics, objectivity; vulnerability; respect

\section{INTRODUCTION}

One of the focus points of contemporary discussion about the future of journalism is the search for a new business model to address the issue of decreasing revenues arising from a drop in financing through advertising, through public entities, and due to changes to journalism brought about by new technologies (Bastos \& Zamit, 2012). Our view is that such debate should include the discussion about the communication model of journalism, namely the ethical and regulatory foundations underpinning the socialprofessional culture of reporters. The imperative to find a business model for mass media to salvage journalism shirks from the heart of the matter, substantially more problematic, which is that of the regulatory foundations of journalism, otherwise suggesting that we are seeking a solution to ensure the status quo. The revolution in new ways of accessing, producing and disseminating information we witness today, in the framework of a new public space, requires new methods of forging the legitimacy and the role of journalism anew, which goes beyond adjusting to the new market conditions.

\footnotetext{
'This research is part of the project "Gendered newsmaking: A gender-sensitive exploration of news production and organizations" undertaken at Centro de Investigação Jornalismo e Media (CIMJ), reference PTDC/IVC-COM/4881/2012, financed through national funds through FCT/MCTES (PIDDAC); The author also wishes to thank Ceis2o - Centro de Estudos Interdisciplinares do Século XX da Universidade de Coimbra for its support on the translation of the text.

${ }^{2}$ Professor of journalism, supervisor of the Master's degree in Communication and Journalism of Coimbra University's Faculty of Letters, and coordinator of the Communication, Journalism and Public Space Research Group, at the Centre for 2oth Century Interdisciplinary Studies (CEIS2O).
} 
The ethics and deontology of journalism focus on issues concerning information quality, in terms of the objectivity, truth and precision of that information (Laetilia, 1995), no matter how painful it may be (Traquina, 2002: 75). This paradigm largely stems from the changes triggered by industrialisation and the professionalization of the trade of journalism in the 19th century (Chalaby, 2003): objectivity, although nuanced in the beginning of the century (Schudson, [1978] 2010: 13 and foll.), emerged as the focus point of new public communication. It is also founded on the utilitarian principle of press as a court for the public opinion (Bentham ([1822-1823] 2001), a service intended to keep watch over the public powers for the lingering threats of corruption (Camponez, 2010: 70-72).

Early ethics codes sought to enshrine the duty of objectivity, based on the principle of an objectivity pact concluded by journalists and media entrepreneurs, sustained on the one side by the autonomy of journalists in relation to publishing policy and, on the other, managing communication companies (Rosen, 2000). Increased content marketing and convergence of media and new information and communication technologies created new media management contexts, which have impacted the trade. Consequently, some authors find that there was a shift from information journalism, particularly in the first three quarters of the 2oth century, to communication journalism (Brin et al., 2004: 292-293). Here, the question is whether such changes place us on the threshold of a new ethos, in view of fitting the professional practice and values of journalism into a more demanding context. Citizens' journalism, cyber-journalism, the shift in the borders of privacy, arising from a new kind of visibility driven by new technologies, hyper-competition in journalism, instantaneous information, powerful sources, multimedia publishing and global media discourse are some of the critical topics from which new practices can emerge. Such practices may question the hierarchy of journalistic values, founded on a less speculative vision of the truthfulness of news.

Journalist and social science's critical view of this model explains the process, identified by Mário Mesquita (2000), of the disappearance of the concept of objectivity from the ethics codes, to give way to other concepts deemed more appropriate, such as rigour, honesty and precision. In effect, one may argue that the relativisation of objectivity as a daily practice and its appreciation as an ideal to be met merely updated the concept, while it did not become a truly critical component, nor was it used to defy the emergence of info-entertainment and show information, in an era of extreme journalistic competition and the growing power of sources of information.

The present paper intends to address these topics against the backdrop of an ethics of care, linked with the dimensions of the social responsibility of journalism, democracy, public space, and the treatment given to the individuals participating in the different stages of the news production process. Very far from denying the paradigm of objectivity, the ethics of care highlights the role of journalism in terms of its commitment to quality in the public sphere and democracy, without prejudice to the journalist's individual freedom and the autonomy of the trade. This view may also help develop the critical detachment needed to rise to new public challenges of the communication era, increasingly subject to the logic of market, audience and entertainment, beginning with the clarification of the grounds for the legitimacy of journalism. 


\section{FROM FEMINIST ETHICS TO THE ETHICS OF CARE}

In 1930 Dewey predicted that "the growing freedom of women can hardly have any other outcome than the production of more realistic and more human morals" (Dewey, [1930] 1984: 276). Although he did not write profusely about women, his views on feminism and democracy touch the heart of ethics as a pragmatic effort to look into problematic social conditions and improve them, in view of improving democratic forms of government, thus enabling a growing number of voices - including women's voices - to take part in decision-making. In his ethical thinking Dewey included further concrete relations, emotions and issues pertaining to character, highlighting and clarifying their importance in moral life. These aspects were addressed separately, by a feminist ethics of care, which finds moral meaning is the core elements of relationships and human ties.

Dewey's ideas had a lot in common with the first Chicago women researchers. Jane Addams, for example, also finds that it does not make sense to assume an ethical stance independent of ones relationship with oneself, with others or with the community. Like Dewey, Addams illustrates how morals can grow from intimate relationships which are paramount for human development. In this scheme of thought there is a dynamic principle of respect for oneself and others, which forces us to take measures that may respond to the person's, other individuals' and communities' perceived needs. This same process also includes experience, the specific, the individual, all of which mediated by communication, negotiation and symbolic exchange.

Almost one hundred years after Addams and Dewey, Richard Sennet brought these questions to social theory by underscoring that it is not enough simply to give an order to guarantee that people are treated with respect, and that mutual recognition must be negotiated (Sennett, 2003: 295), with the inherent complexities of personal character and social structure intervening.

The 1980s inaugurates "the second wave of feminism" in the United States of America, and with it the "adventure of care" (Moliner, et al., 2009: 8). This process is marked by the criticism which Carol Gilligan directed, in In a Different Voice: Psychological Theory and Women's Development ([1982] 1997) at Lawrence Kolhberg's ([1981] 1992) psychology of moral development. In a study of moral development, Kolhberg compares the reasoning of Jake and Amy, an 11 year old boy and girl, about Mr Heinz, who needs to buy medicine to save his dying wife, but for which he has no money to pay the pharmacist. Regarding what Mr Heinz should do, Jake believes he should steel the medicine, and argues that if he is caught the judge will understand the underlying reason for his act, for which he will be only lightly convicted; Amy discusses other negotiation-type of solutions for Heinz to get the money he needs for the treatment, thus avoiding both theft and the death of his wife. Gilligan takes a stand against Kolhberg's conclusion that Jake, compared to Amy, was in a more mature stage of (moral) logical-deductive thought, and does not consider the possibility, in fact, of these being two different approaches to solving moral dilemmas: an impersonal, resorting to logic and Law; another, personal, using communication and human relations. 
In Gilligan's view, the reasons for such approach have to do with the nature of the hegemonic thought of a patriarchal moral which values autonomy and reasoning as developmental criteria (Gilligan, 2009:76), an opinion which she will include in an open criticism directed at the formalist theories of Kantian nature, as is the case of Rawls's Theory of Justice. Therefore, one might say that more than intrinsic criteria of morals, autonomy and rationality, which feature in formalist theories' tradition of thought, reflect a certain (patriarchal) view of morality. In this context, more than reforming the theories of justice, it is the paradigm of moral thought that should be modified.

While Gilligan's criticism embodied several concepts which lent coherence and meaning to the experience of many women (Molinier et al., 2009: 10), it also attached the ethics of care to feminine ethics and triggered a set of critical reactions, arising from philosophical ethics.

\section{EXPANDING THE ETHICS OF CARE}

By positioning itself as criticism directed at the theories of justice, the ethics of care was labelled as individual ethics, and caused several traditionally problematic and ambiguous concepts of ethical and philosophical thought to appear: fair and important; autonomy and vulnerability; rationality and sensitivity; general and individual; public and private.

However, as Maria João Silveirinha puts it, although the ethics of care is found to be close to community ethics, the connection between the two is unclear (Silveirinha, 2014). While some authors tend to classify feminist ethics as "feminist communitarianism", founded on the assumption that the community is ontologically and axiologically prior to people, the fact remains that, in Gilligan's ethics of care, more than women's issues we find human concerns. Therefore, the researcher finds that the real questions must be asked, namely how issues of justice and rights intersect questions concerning care and responsibility. Gilligan says:

\footnotetext{
"The moral injunction - do not oppress, do not exercise power unfairly or take advantage of other - lives side by side with the moral injunction to not abandon, to not act carelessly or neglect people who need help, meaning everyone including oneself. Once it is clear that the different voice with its ethic of care resists patriarchal hierarchies, it becomes easier to grasp the reasons for common misunderstandings and mistranslations of my work, to recognize how parts of my original text contributed to these misunderstandings, and also to see how these misinterpretations reflect an assimilation of my work to the very gender norms and values I was contesting" (Gilligan, 2009: 77).
}

In this context, Patricia Paperman and other authors emphasise the need to break away from this philosophical dualism, in order to incorporate the issues of sensitivity which are all too dear to the ethic of care. In this perspective, the solution lies in overcoming dualism communitarianism /liberalism, through an episteme which incorporates sensitivity as a form of moral knowledge and action. 
"Against the idea that emotions are a barrier to reason and immorality, the source of biased and distorted moral reasoning, feminists are not the only ones to value the epistemic and moral value of emotions, in particular in the field of personal relations. The perspective of care - unlike other emotion analyses - includes this epistemic dimension as a corollary of the attitudes and practical activities which are essential for us. Moral knowledge and understanding emerge, not as a complement, but as an aspect of sensitive and active attention directed towards the other" (Paperman, 2009: 96).

Within this framework of thought, Joan Tronto (2009) describes three dimensions of care: care about someone or something, as openness to acknowledge the need of the other person; care-giving, as a technical and moral skill; care receiving, as the capacity for self-assessment and to react to the way others receive our care.

\section{DEMOCRATISING CARE}

Tronto also draws attention to the need to democratise the concept of care itself, which will otherwise still be relegated to the individual's ethics, away from the public sphere, therefore remaining politically discredited. Besides overshadowing the ethics of care as a feminist ethics, the aforementioned circumstance is also a way of discrediting the trades which deliver social services and which are themselves the expression of other social inequalities, of both gender, class and race.

To remedy the situation the notion of vulnerability and respect must be transformed into the core concept of living together, as opposed to the concept of autonomy. According to Tronto, this implies admitting, not only that during our childhood we need care and that one day we become fragile or are ill, but above all that each and everyone of us requires care in our everyday life, as part of our human condition. In this framework, care is not only something for those who need it or for those who guarantee its provision, but it is also a public and political requirement across society.

"This is not an idea that most people easily accept. It assumes that we see ourselves as being vulnerable. It assumes that we abandon the feeling of full autonomy. And it requires that we stop thinking that 'individual autonomy' is the solution for all of society's problems. In effect, true acknowledgement of our profound vulnerability and that it is what ties us to others can very well change the way we think about social responsibilities" (Tronto, 2009:51).

Gilligan in turn underscores this democratic dimension of the ethics of care by holding that the structurally unequal nature of patriarchal ethics implies a new language focused on what is truly human, on respect and on the ideal of equality, thus forcing us to shift from a paradigm centred on the concern for the legitimacy of who should be listened to, to the paradigm of merely Listening (Gilligan, 2009). 


\section{THE DEBATE BETWEEN COMMUNITARIANS AND LIBERALS IN THE MEDIA}

These discussions recall the debate between liberals and communitarians on the ethics of media and journalism, brought to us by authors like Christians (2004), Merrill (1997), Lambeth ([1986] 1992), to name but a few. We find one ultimate expression of such tension in Merrill, who advocates deontelic practice for journalists (Merril, 1997: 214) or apollonysian journalism (Merrill, 1981: 134), by seeking to reconcile Deontology - in the philosophical sense of an ethics of principles - and Teleology - in line with a communitarian ethics of the ends -, including rationality and sensitivity. However, even if we embrace this as a loose and less radical version of Merrill's (Fidalgo, 2007:358-359) standpoint, one may say that it strives to connect irreconcilable theoretical assumptions and, to some extent, it is merely an attempt to provide an escape for a problem, while leaving untouched - and unsolved - its root assumptions.

As we see it, the inputs of the ethic of care and of the respect for the communication and journalistic fields fits in with a series of problems raised in the context of civic journalism and in what could also be regarded as an ethics of proximity. Both, however, are entangled in strictly communitarian problems which have made progress in the discussion difficult. The defense of civic journalism comes up systematically against founded criticism arising from what is perceived as the relativisation and silence of truth and, in some cases, against the freedom of expression itself, in the framework of an communitarian ethics (Jackson, 2003). As for what might be referred to as an ethics of proximity, it has also been the subject of broad discussion, which has unveiled its fragilities and dangers in relation to its condescension of established local powers (Coelho, 2005) and to the distortion of truth, in situations where 'good causes' justify the manipulative means serving such causes (Camponez, 2002). The situation is even worse since the polysemy of proximity has given rise to all kinds of perversive communication, namely as far as psychological and social proximity are concerned, and its retrieval from a strictly sensationalist and market perspective.

Steiner and Okrusch, on the other hand, criticised a prevailing model of journalism very close to an ethics of rights, to tight Kantian principles and utilitarian defense of objectivity, in the light of which journalists are urged to exclude from news their personal views, experiences and standpoints that must not even interfere with their decisions on what is news, or what sources to listen to.

“Journalists' ideas, experiences, perspectives, prejudice—if they have them at allshould never enter into decisions about what is newsworthy or what topics are worthy of journalistic investigation, who should be used as sources or quoted, and a host of other questions that turn out to be not merely professional, but also ethical. (...) [The] reference to justice is invoked to motivate journalists to expose injustice and unfairness -including in governmental and business sectors-to help "right" the system. Even so, this is a thin ethic. Moreover, conventional criteria of newsworthiness-timeliness, proximity, prominence, impact, human interest, and so forth-are ethically empty. Such definitions offer no help to journalists who might want to pursue justice and in the meantime, must make judgments about topics, sources, length, graphics, and so forth" (Steiner \& Okrusch, 2006: 103). 
With this we come back to the criticism of the concept of journalistic objectivity as a strategic ritual, as mentioned by Gay Tuchman ([1972] 1993) or the theses which support recasting the concept in view of the changes which have taken place both in the field of media (Rosen, 2000) and in the epistemic field itself.

Schudson showed how journalism in the late 19th and early 2oth centuries organised itself around the idea of separating facts from values; he defined the former as statements on the world which can be assayed independently, whereas the latter are like subjective viewpoints and presumptions about the world which must be taken out of news reports.

This objective-rationalist model, possibly the heir to 18th century Enlightenment, but definitely to positivism and to scientific progress in the following century, is also the result of great changes in the media which occurred in the second half of the 1800 s. The industrialisation of press, the professionalisation of journalism, the emergence of news agencies, conveying information by telegraph and the search for increasingly vast audience, enforced new practices and narratives consistent with what Daniel Cornu called objectivity adjusted to market conditions (Cornu, 1994: 203). Several studies show that these trends not only did not disappear from the field of journalism, but also grew in the beginning of this century, hereby producing more homogeneous and lighter news, both in terms of public topics, and in terms of the discourse, and the variety of narratives (Patterson, 2003).

In spite of the criticism targeted at the faith in facts after the 1st World War, in the framework of journalism and of academia, "the ideal of objectivity has by no means been displaced, but, more than ever, it holds its authority on sufferance." ( Schudson, [1978] 2010: 20).

\section{OBJECTIVITY AND FREEDOM OF SPEECH}

Nevertheless, what is still striking in that change is the fact that journalism, in terms of norms, has managed to combine the principles of rigour and commitment with truth and objectivity, while preserving its ideological and legal foundations, connecting it to the subjectivist principles of freedom of speech, associated with the political and opinion press model. When John Milton sustained freedom of speech and the end of censorship, he did so based on the presumption that truth and error were realities which were not clear for the individual and could only be distinguished through a dialogic process of communication, fostered by freedom of speech (Milton [1644]1999: 161). Through this way of thinking, the author of Areopagitica shifts the issue of truth from the political and religious power to the individual, based on the assumption that the individual has the capacity of self-determination, and uses reason to understand the world around him. Enlightenment sought, to some extent, to build these freedoms on the belief in a reason devoid of sensations and emotions. Wherefore, illuminist thought itself implicitly imagined correction factors of the ideals of free public use of reason, by requiring of individuals education, schooling and economic autonomy, based on the assumption that these class features would ensure enhanced quality of the public debate. Which is 
why, in Kant's view, State citizens, who enjoyed legislative power, should be learned and economically independent; besides the proceeds which their knowledge and skills have brought them, they must own property (Kant, [1794] 2002: 80-81). This is perhaps a further reason for Kant to consider that $18^{\text {th }}$ century Lights were still far from corresponding to a real "period of Enlightenment" (Kant, [1784] 2002: 17).

The objectivity ideal in journalism did not erase the marks of thought which tie it to the intellectual and political past of press, before the second half of the 19th century. In 1928, the Bureau International du Travail, on working and living conditions of journalists, in this respect, stated the following:

"The journalist is not merely a wage earner; he is, as a rule, a man of opinions and convictions, and employs them in his work. Whereas in many other professions political opinion and religious convictions may be quite unconnected with the work to be done, it does not matter whether one is a conservative or a radical for the purpose of making watches or nursing the sick or building bridges - the opinions and convictions of a journalist are more often than not one of the necessary elements of his trade. (...) The attachment which every man has or should have for the opinions of others, confers upon journalism an unquestionable right to esteem, although at the same time they expose it to certain danger. Upheavals in the realm of ideas have disastrous effects on the livelihood of journalists much more so than economic upheavals" (Apud Jones, 1980: 12-13).

Approximately fifty years later, Merrill and Barney ([1975]1981: 13) reiterated that the journalist is not a mere producer of contents to be consumed by others; he is also someone who, in doing so, expresses himself and gives himself wholly to this activity that he carries out. Still it is in the name of objectivity that journalists discuss their involvement in politically charged activities ${ }^{3}$, or that companies sustain their decision to dismiss Peter Arnett, at NBC News, in 2003, for delivering his personal opinions and comments on the Iraqui war to a Baghdad television station.

\section{FROM THE ETHICS OF CARE TO THE ETHICS OF JOURNALISM}

It is not possible to address here all critical research conducted into journalistic information and the impact thereof on public discussion. Besides, to place the concept of truth and objectivity in journalism at the heart of all challenges faced by journalism, and to forget the organisational, economic and corporate contexts, would be equally unreasonable. Anyhow, there is the idea that objectivity, as the moral philosophy of the journalistic trade, has not managed to respond convincingly to many challenges facing journalism, particularly relating to standardisation and absence of diversity in informational

\footnotetext{
${ }^{3}$ Cases like the participation of Alfredo Maia, the president of the Journalists' Union, in the candidate list to Porto Municipal Assembly in 2002, and the appointment of Fernando Lima, former advisor to the then prime minister Cavaco Silva, as the director of Diário de Notícias daily newspaper in 2003, are examples of a similar discussion held in Portugal.
} 
contents, the hyperbolisation of language, sensationalism, news made increasingly superficial and light, hybridisation of information and entertainment, and excessive reliance on organised sources of information, among other issues. These dimensions impacted on ethical and deontological aspects of the profession, such as privacy violation, growing inability to diversify and check sources, wrongful use of means of collecting information. In this context, even if we accept that none of this compromises the status of truth of public information, it would be enough to prove that journalistic objectivity - albeit essential - does not in itself guarantee the quality of the debate on public topics. Besides, it can be a standardisation factor of the thinking of journalists themselves, thus restricting the freedom of speech, viewpoint and sensitivity that enhanced internal democracy in editorial offices and greater public diversity in news require. As stated by Chomsky and McChesney (2000: 100), the most radical accusation we can make against commercial media is that emanating from several studies, according to which the more information we consume the less capacity we will have to understand public and political facts.

The objectivity model, based on a rationalist outlook, disconnected and with cold feelings, forces journalists to wipe out their personal experiences, while organisational hierarchy and routine will continue to standardise their work. The power of these values in the culture of the trade - which, as we saw, according to feminist criticism, correspond to patriarchal standards for understanding public life - for example, help us explain why the alleged feminisation of editorial offices in the past decades has not translated into a different culture; the canonical model is mostly replicated ${ }^{4}$ (Steiner, 2008).

Resorting to the ethics of care and respect in a framework of journalistic ethics helps offset issues concerning the narrow view of the objectivity ideology, without however denying journalist's commitment and duty to speak the truth as mediators of public discourse. On the contrary, considering truth as an essential and transversal requirement of the respect owed to the different stakeholders in the general context of communication ethics, the ethics of care raises it to a level of complexity more commensurate with epistemic and normative requirements of contemporary journalism. Journalism focused on values of care must include the dimension of the journalist's respect for himself, for the general public, for the sources, for the topics addressed in the journalistic narratives and for journalism, as a trade committed to providing a public service which is important for the quality of social life and democracy, in terms of a community outlook, and in a context of growing global communication.

Likewise, the ethics of care may help us understand the necessary frameworks for finding new narratives in media, renewing the topics addressed, incorporating the strategies for listening better to citizens - including their criticism of journalists -, in a context

\footnotetext{
${ }_{4}^{4}$ On domestic crime involving gender issues, Rita Basílio de Simões shows how detachment and objectivity translate into models where the coverage by the journalist focuses on the victims as far as their stories are valued by the market, while the dimension connected with the complexity of the crime is granted nowhere near the same importance. This type of approach is reflected in the way domestic violence is treated in news reports; in the case of male perpetrators, the cause of the violence is linked with state of drunkenness, jealousy, emotional imbalance, and sometimes justified by the spouse's breach of his 'obligations', whereas in the case of female perpetrators, the causes are mostly related to weak morals or features of female temper. (Simões, 2014)
} 
of, on the one hand, epistemic demand, and on the other norms, founded on public service, and not only as strategic forms of market and audience enhancement.

This dimension of journalistic service is the mere transposition to the field of media of the universal value of subject vulnerability, as proposed by feminist ethics. It requires sensitive professionals concerned about the world around them (care about), competent professionals when addressing public issues (care giving), and professionals concerned for their trade and actively committed to self-regulation, while enjoying the protection of social institutions and law (care receiving).

\section{Conclusion}

Examining the possibility of an alternative ethics for journalism, based on the assumptions of respect and care, the dimension of the duty of truth, objectivity and information accuracy is not challenged. The ethics of care not only recalibrates these concepts, but also, as one may say, pursues them in the effort to understand human activity, the values which are news and the facts which are newsworthy. An ethics of care also includes the respect for the stakeholders - the journalist, sources, the topics targeted by the information, the audience and the journalism per se -, as a dialogic process of producing and constructing news and in terms of the responsibility to educate public opinion. More than new ethics, the question is how to combine the issues of regulation and ideology in journalism with its practices and, also, with the criticism to which both trade and academy submitted the concept of journalistic objectivity in the 2oh century, thus shifting it from an observable reality to a dialogic dimension in an on-going process of construction. This approach requires of the journalist the sensitivity to understand the other person, to perceive other dimensions of our living together, to identify topics which have been silenced and to question a profession that, due to the routines involved in the production of news, includes a significant dimension of short-lived truths and high likelihood of committing mistakes.

Therefore, more than rejecting the objectivity ideal - respect in communication also entails an essential commitment to truth -, the ethics of care may permit us to redesign epistemologically speaking the objectivity of journalism which, although underestimated in deontological terms, is still regarded as the ideal value, founded on rationality, autonomy and detachment.

While it is true that today one cannot accuse reporters of being blinded by this concept of objectivity in their daily work, an ethics which constitutes a new public commitment to truth is needed. About this, journalism was very sparing with thought, or more precisely, the criticism to which the concept was submitted, specially from the $1960 \mathrm{~s}$ onwards, did not produce anything really new.

As Schudson points out, journalists' ethical commitment to objectivity cannot be disconnected from a public and a philosophical moral. Therefore, the paradigm shift translates into an ethics of objectivity which is no longer focused only on independence, detachment, interest/relevance, distribution, legitimacy of who speaks, what the 
audience should or wants to hear, and becomes more committed to Listening and respects the parties heard more, which does not mean agreeing with what is said.

Finally, while the thoughts submitted are part of a personal study of journalism, the inputs thereof can be extended, in our view, do other communication fields, whose principles seek to free professions from strictly functional and strategic logics.

\section{REFERENCES}

Addams, J. (1902), Democracy and social ethics, Nova Iorque: Macmillan Co.

Bastos, H. \& Zamit, F. (2012), Ciberjornalismo Modelos de Negócio e Redes Sociais, Porto: Edições Afrontamento.

Bentham, J. ([1822-1823] 2001), 'Garanties contre l'abus de pouvoir', in Bentham, J. (2001), Garanties Contre L'Abus de Pouvoir et Autres Écrits Sur la Liberté Politique, Paris: Editions Rue d'ULM.

Camponez, C. (2010), 'Os impasses sobre a liberdade de imprensa no pensamento utilitarista', in Camponez, C. \& Peixinho, A. T. (20010), Reflexões Sobre a Liberdade: 150 Anos da obra de John Stuart Mill, Coimbra: Imprensa da Universidade de Coimbra, pp. 69-78.

Chalaby, J. (2003), 'O jornalismo como invenção anglo-americana: Comparação entre o desenvolvimento do jornalismo francês e anglo-americano (1830-1920)', Media Q Jornalismo, n. ${ }^{\circ}$ 3, 2003, pp. $29-50$.

Chomsky, N. \& McChesney, R. (2000), Propagande, Médias et Démocratie, Montréal: Écosocieté.

Christians, C. G. (2011), 'Universalism versus communitarianism in media ethics', in Fackler, Robert S. Fortner and P. Mark (eds.) (2011), The Handbook of Global Communication and Media Ethics, Vol II, Malden, MA: Wiley-Blackwell, pp. 393-414.

Coelho, P. (2005), A TV de Proximidade e os Novos Desafios do Espaço Público, Livros Horizonte, Lisboa: 2005.

Dewey, J. ([1930]1984), 'What I believe', in Boydston, J. A. (ed.) (1984), John Dewey: The later works, 1925-1953, Vol. 5, Carbondale and Edwardsville: Southern Illinois University Press, pp. 267-278.

Fidalgo, J. (2007), O Lugar da Ética e da Auto-Regulação na Identidade Profissional dos Jornalistas, Tese de doutoramento defendida na Universidade do Minho, disponível em: http://hdl.handle.net/1822/6011 (consultado em 24/03/2014).

Gilligan, C. ([1982] 1997), Teoria Psicológica e Desenvolvimento da Mulher, Lisboa: Fundação Calouste Gulbenkian.

Gilligan, C. (2003), 'Le care, éthique féminine ou éthique féministe ?’, Multitudes, 2009/2 n 37-38, p. 76-78.

Jackson jr, W. E. (2003) 'Salvemos a democracia do jornalismo cívico', in Traquina, N. \& Mesquita, M. (eds.) (2003), Jornalismo Cívico, Lisboa: Livros Horizonte,

Kant, I. ([1784] s.d.) 'Resposta à pergunta: Que é o iluminismo?’, in Kant. I ([1784] s.d.), A Paz Perpétua e Outros Opúsculos, Lisboa: Edições 70, pp.11-19.

Kant, I. ([1793] s.d.), 'O fim de todas as coisas', in Kant. I ([1784] s.d.), A Paz Perpétua e Outros Opúsculos, Lisboa: Edições 70, pp.103-118.

Kohlberg, Lawrence ([1981] 1992), Psicología del Desarrollo Moral, Bilbao: Editorial Desclée de Brouwer. 
Laitila, T. (1995), 'Journalistic codes of ethics in Europe?, European Journal of Communication, Vol. 10 (4), Londres, Thousand Oaks e Nova Deli.

Lambeth, E. B. (1992) Committed Journalism: An ethic for the profession, Bloomington, Ind.: Indiana University Press.

Merril, J. C. (1981), 'El periodista 'apolonisíaco', in Merrill, J. C. \& Barney, R. D. (1981), La Prensa y la Ética : Ensayo sobre la moral de los medios masivos de comunicación, Buenos Aires: Editorial Universitaria de Buenos Aires, pp. 134-150.

Merrill, J. C. (1990). The Imperative of Freedom: A philosophy of journalistic autonomy, Lanham: Univ. Press of America.

Merrill, J. C. (1997) Journalism Ethics : Philosophical foundations for news media, Nova lorque: S. Martins's Press.

Merrill, J. C. \& Barney, R. D. (1981), La Prensa y la Ética : Ensayo sobre la moral de los medios masivos de comunicación, Buenos Aires: Editorial Universitaria de Buenos Aires.

Mesquita, M. (janeiro-março de 2000), 'Em louvor da Santa Objectividade', in JJ - Jornalismo e Jornalistas, $\mathrm{n}^{\circ} \mathrm{1}$, Lisboa: Clube dos Jornalistas.

2000, pp.22-27.O Quarto Equívoco - O poder dos media na sociedade contemporânea, Coimbra: MinervaCoimbra.

Milton, J. ([1644]1999), Areopagítica - Discurso pela liberdade de imprensa ao Parlamento da Inglaterra, Rio de Janeiro: Topbooks.

Moliner, P., Laugier, S., \& Papperman, P. (2009), Qu'Est-ce Que le Care ?: Souci des autres, sensibilité, responsabilité, Paris: Éditions Payot \& Rivages.

Paperman, P. (2009), 'D'une voix discordante : désentimentaliser le care, démoraliser l'éthique', in Moliner, P., Laugier, S., \& Papperman, P. (2009), Qu'Est-ce Que le Care ?: Souci des autres, sensibilité, responsabilité, Paris: Éditions Payot \& Rivages, pp. 89-110.

Rosen, J. (Fevereiro de 2000) «Para além da objectividade», Revista de Comunicação e Linguagens («Jornalismo 2000»), n. ${ }^{\circ} 27$, Lisboa, 2000.

Schudson, M. ([1978] 2010), Descobrindo a Notícia: Uma história social dos jornais nos Estados Unidos, Petrópolis: Editora Vozes.

Sennett, R. (2003), Respect: De la dignité de l'homme dans un monde d'inegalité, s.l.: Hachette.

Silveirinha, M. J. (2014) 'Comunitarismo: da filosofia política à comunicação e ao feminismo', texto policopiado, pp. 1-22.

Simões, R. B. (2014), Crime, Castigo e Género nas Sociedades Mediáticas: Políticas de (in)justiça no discurso dos media, Lisboa: Media XXI (no prelo).

Steiner, L, \& Okrusch, C. M. (2006), 'Care as a virtue for journalists', in Journal of Mass Media Ethics, 21, (2 e 3), pp. 102-122.

Steiner, L. (2008), 'Critiquing Journalism: Feminist Perspectives Relevant to Contemporary Challenges', in Poindexter, P., Meraz, S. \& Weiss, A. S. (2008), Women, Men, and News: Divided and disconnected in the news media landscape, Nova lorque: Routledge, pp. 281-87.

Traquina, N. (2002), Jornalismo, s.I.: Quimera Editores 
Tronto, J. (2009), 'Care démocratique et démocraties du care', in Moliner, P., Laugier, S., \& Paperman, P. (2009), Qu'Est-ce Que le Care ?: Souci des autres, sensibilité, responsabilité, Paris: Éditions Payot \& Rivages, pp. 35-55.

Tuchman, G, ([1972] 1993), 'A objectividade como ritual estratégico: Uma análise das noções de objectividade dos jornalistas', in Traquina, N. (ed.) (1993), Jornalismo: Questões, teorias e 'estórias', Lisboa: Veja.

Van Zoonen, L. (1998). 'One of the Girls? The Changing Gender of Journalism', in Carter, C., Branston, G., \& Stuart Allan (1998), News, Gender and Power, London: Routledge, pp. 33-46.

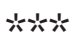

Received: 18-03-2014

Accepted: 05-05-2014 